\title{
Multi-locational Screening of Genotypes of Cowpea [Vigna unguiculata (L) Walp] for Resistance to Viral Infection
}

\author{
Essandoh A. Vera ${ }^{1}$, Asare-Bediako Elvis ${ }^{1^{*}}$, Asare Tettey Aaron ${ }^{2}$, Kusi Francis $^{3}$ \\ and Aboagye Misah Lawrence ${ }^{4}$
}

${ }^{1}$ Department of Crop Science, School of Agriculture, University of Cape Coast, Cape Coast, Ghana. ${ }^{2}$ Department of Molecular Biology and Biotechnology, School of Biological Sciences, University of Cape Coast, Cape Coast, Ghana. ${ }^{3}$ CSIR-Savannah Agriculture Research Institute, Manga, Ghana. ${ }^{4}$ CSIR-Plant Genetic Resource Research Institute, Bunso, Ghana.

\section{Authors' contributions}

This work was carried out in collaboration between all authors. All authors performed the experiment. Authors EAV, ABE and ATA designed the study, wrote the protocol and the first draft of the manuscript. Authors EAV and ABE managed the analyses of the study. Author EAV managed the literature searches. All authors read and approved the final manuscript.

Article Information

DOI: $10.9734 / A R R B / 2017 / 34547$

Editor(s):

(1) J. David Puett, Department of Biochemistry and Molecular Biology, University of Georgia, Georgia.

(2) George Perry, University of Texas at San Antonio, USA.

Reviewers:

(1) Essam Fathy Mohamed El-Hashash, Al-Azhar University, Egypt.

(2) M. Ali Sevik, University of Ondokuz Mayis, Turkey.

(3) P. V. Krishna, Acharya Nagarjuna University, India.

Complete Peer review History: http://www.sciencedomain.org/review-history/19993

Original Research Article

Received 31 $1^{\text {st }}$ May 2017

Accepted $28^{\text {th }}$ June 2017

Published 11 $1^{\text {th }}$ July 2017

\section{ABSTRACT}

Viral diseases are an important biotic constraint to cowpea production in sub-Saharan Africa. The use of resistant varieties is the most effective approach in managing viral diseases. In order to identify sources of resistance, thirty two cowpea genotypes were evaluated in field trials at coastal savannah, Sudan savannah and semi-deciduous forest agro-ecological zones of Ghana during 2015 major cropping season. The experiments were laid out in a randomized complete block design with four replications. Viral disease severity was assessed at 8 weeks after planting (WAP) based on 1-5 
visual scale $(1=$ no symptom, $5=$ very severe symptom). All the cowpea genotypes at the various locations showed symptoms of viral diseases but at varying degrees. However, the levels of incidence and severity were generally low and varied significantly $(P<0.05)$ with locations, with forest zone having the highest incidence of $30.79 \%$, and severity score of 1.354 whilst Sudan savanna zone had the lowest incidence of $5.62 \%$ and severity score of 1.036 . Genotypes Apagbaala, UCC-366, UCC-473, UCC-484, UCC-489, UCC-490, UCC-497, UCC-514 and UCC-523 showed field resistance (mild symptoms) at all three agro-ecological zones. Genotype $x$ location $(G X L)$ interaction effects on mean incidence and severity were however, not significant $(P>0.05)$. Results also showed significant differences among genotypes, locations and GXL interaction effects on plant height, canopy diameter, 100 -seed weight and seed yields $(P<0.05)$. Overall mean seed yield at UCC (5.25 $\left.\mathrm{t} \mathrm{ha}^{-1}\right)$ was significantly higher than Bunso (1.186 $\left.\mathrm{t} \mathrm{ha}^{-1}\right)$ and Bawku $(1,188 \mathrm{t} \mathrm{ha}$ $\left.{ }^{1}\right)$. Therefore genotypes that was resistant to viral infection and also gave high seed yields should be further evaluated and released as a variety for the locations where they performed better.

Keywords: Cowpea; varietal screening; viral disease; resistance to viral infection; genotype $x$ location interaction.

\section{ABBREVIATION}

AEZ: Agro-ecological zone

\section{INTRODUCTION}

Cowpea (Vigna unguiculata, L. Walp) plays a critical role in the lives of millions of people in Africa and other parts of the developing world, where it is a major source of dietary protein that nutritionally complements staple low-protein cereal and tuber crops. It also serves as a valuable and dependable commodity that produces income for farmers and traders [1,2]. Cowpea is rich in potassium with good amount of calcium, magnesium and phosphorus and has small amount of iron, sodium, zinc, copper, manganese and selenium. Cowpea is also rich in vitamin $A$ and $C$ and has appreciable amount of thiamin, riboflavin, niacin, vitamin B6 and pantothenic acid as well as small amount of foliate. In Ghana cowpea is generally prepared and eaten as a whole or as part of a meal. Early maturing cowpea varieties can provide the first food from the current harvest sooner than any other crop (in as few as 55 days after planting), thereby shortening the "hungry period" that often occurs just prior to harvest of the current season's crop in farming communities in the developing world [3]. Cowpea is a valuable component of farming systems in many areas because of its ability to restore soil fertility for succeeding cereal crops grown in rotation with it [4-6].

Despite the numerous nutritional and socioeconomic importance of cowpea, its production in Ghana is faced with numerous constraints leading to low yields. The current average yield of cowpea in Ghana is just 1.3 metric tonnes per hectare far below the potential yield of 2.6 metric tonnes per hectare [7]. Diseases induced by pathogens such as higher parasitic plants, nematodes, fungi, bacteria and viruses are a major constraint to commercial cowpea production worldwide [8]. A yield loss estimate of $15-87 \%$ due to Cowpea aphid-borne mosaic virus infections on cowpea was reported in Iran [9]. Taiwo et al. [10] also reported yield losses between $20 \%$ and $100 \%$ due to viral infection of irrigated cowpea fields in northern Nigeria. Common symptoms associated with viral infection of cowpea include leaf yellowing, mottling, mosaic, necrotic spots and blisters on leaves, green and yellow vein banding, leaf deformation, witches broom, defoliation, apical necrosis and stunting or even plant death [11].

Over 140 viruses worldwide have been reported to attack cowpea and at least 11 of these occur in Africa [12]. Viruses so far reported to be infecting cowpea in Ghana include Southern bean mosaic virus (SBMV), Cowpea aphid-borne mosaic virus (CABMV), Blackeye cowpea mosaic virus (BICMV) and Cowpea mild mottle virus (CPMMV) [13,14].

Strategies aimed at plant virus disease management are largely directed at preventing virus infection by eradicating the source of infection to prevent the virus from reaching the crop, minimizing the spread of the disease by controlling its vector, utilizing virus-free planting material and incorporating host-plant resistance to the virus [12]. Karim [15] stated that although most farmers practice strict monitoring or calendar spraying with chemical insecticides to control insects that vector these viruses, they still observe severe yellowing on plants and probably 
could be due to the fact that viruses responsible for the yellowing are not mainly insecttransmitted. The development of resistant cultivars has therefore been universally considered the most effective method to control diseases caused by viruses in cowpea [16]. An increase in the number of virus resistant genotypes will generate more alternatives for breeders to produce resistant cultivars. Hence, the objective of this study was to evaluate recombinant inbred lines of cowpea for enhanced agronomic and viral resistance traits in different agro-ecological zones of Ghana.

\section{MATERIALS AND METHODS}

\subsection{Study Area}

Field experiments were conducted at three agroecological zones in Ghana from July to October 2015 during the major cropping season. The three locations were University of Cape Coast, Cape Coast, in the coastal savannah agroecological zone (AEZ); Plant Genetic Resources Research Institute, Bunso, in the Semideciduous forest AEZ; and Savannah Agriculture Research Institute (SARI), Manga, in the Sudan savannah AEZ.

\subsection{Plant Materials}

A total of 32 cowpea genotypes were used for the study. This comprised 28 accessions from UCC (UCC-Early, UCC-White, UCC-11, UCC-24, UCC-32, UCC-56, UCC-122, UCC-153, UCC221, UCC-226, UCC-241, UCC-328, UCC-366, UCC-377, UCC-428, UCC-445, UCC-460, UCC466, UCC-471, UCC-473, UCC-478, UCC-484, UCC-489, UCC-490, UCC-497, UCC-513,UCC514, UCC-523); 2 genotypes from SARI (Apagbaala and SARC-LO2); 1 genotype (IT97K499-35) from IITA, Nigeria and 1 genotype (GH3684) from PGRRI, Bunso, Ghana.

\subsection{Experimental Design and Field Layout}

The randomized complete block design with 32 treatments (cowpea genotypes) and four replications was used. A total land area of 2185 $\mathrm{m}^{2}$ measuring $23 \mathrm{~m} \times 95 \mathrm{~m}$ was ploughed and harrowed to render the soil loose. It was then divided into four blocks, spaced $1 \mathrm{~m}$ apart, and each block was further divided into 32 plots, spaced $2 \mathrm{~m}$ apart, and a plot size of $2 \mathrm{~m} \times 4 \mathrm{~m}$. Three seeds were sown per hill with an inter row spacing of $50 \mathrm{~cm}$ and intra-row spacing of $50 \mathrm{~cm}$ and later thinned to two seedlings per hill. The experiment was under rain-fed conditions. Weeding was done manually using machete and hoe, when necessary.

\subsection{Data Collection}

Data was collected on disease incidence and severity, plant height, canopy diameter, 100 -seed weight and seed yield. In each case data was taken from 10 inner rows of each plot and the mean per plant determined. Data on disease incidence and severity were assessed at 8 weeks after sowing, based on disease symptoms described by Gumedzoe et al. [17].

Incidence of virus disease for the various fields was calculated using the formula by Galanihe et al. [18].

Disease incidence $=\frac{\text { number of infected plants }}{\text { total number of plants }} \times 100$

The severity of cowpea viruses in each field was assessed based on the 1-5 symptoms severity scale developed by Gumedzoe et al. [17] as shown in Table 1.

\subsection{Data Analysis}

Data on percentage incidence from the various fields was transformed using angular transformation before subjecting to analysis of variance (ANOVA). The other quantitative data (disease severity, plant height, canopy diameter, 100 seed weight and seed yield) were also subjected to ANOVA, and the means were separated using least significant difference (L.S.D.) method at $5 \%$ level of probability. All statistical analyses were performed using Gen Stat Release version 12 (VSN International).

Table 1. Visual scale for assessing severity of cowpea viral disease

\begin{tabular}{ll}
\hline Scale & Symptom description \\
\hline 1 & no symptoms on all leaves \\
2 & slight symptoms ( 1 to $25 \%$ of the leaves infected) \\
3 & moderate symptoms ( 26 to $50 \%$ leaves infected) \\
4 & prominent symptoms with stunting $(51$ to $75 \%$ of leaves infected) \\
5 & highly severe symptoms with stunting $(>75 \%$ of leaves infected) \\
\hline
\end{tabular}




\section{RESULTS AND DISCUSSION}

\subsection{Mean Incidence of Viral Diseases}

ANOVA on final disease incidence showed significant differences among the cowpea genotypes at Bawku $\left(F_{31,93}=1.60 ; P=0.043\right)$ and UCC $\left(F_{31,93}=2.22 ; P=0.002\right)$ but did not show any significant difference at Bunso $\left(\mathrm{F}_{31,93}=1.46\right.$; $\mathrm{P}=0.086$ ) (Table 2). At Bawku, mean disease incidences ranged from $0 \%$ (no symptom) for genotypes UCC-11, UCC-241, UCC-366, UCC466, UCC-473, UCC-478, UCC-514, Apagbaala, IT97K-499-35 and UCC-White, to $21.024 \%$ for genotype UCC-32. At UCC, the mean disease incidence ranged from $0 \%$ (no symptom) for genotypes UCC-24, UCC-471, UCC-478 and Apagbaala, to $33.71 \%$ for genotype UCC-White (Table 2). Mean disease incidence recorded for the cowpea genotypes at Bunso ranged from $9.81 \%$ recorded for Apagbaagla to $59.94 \%$ recorded for UCC-Early (Table 2).

The significant differences in disease incidence exhibited by the cowpea genotypes at various locations could be as a result of the variation in their genetic architecture. According to Grumet et al. [19] genetic background may influence the apparent relative effectiveness of the resistance genes of the plant, resulting in a lot of genotypes becoming susceptible to a virus attack. Significant differences in disease incidences could also possibly be attributed to the fact that the vectors had an affinity for some particular genotypes than others and resulted in some genotypes being more susceptible to the virus than others. This probably made them feed and transmit the virus following their longer stay on those plants. This corroborates the findings of Osei et al. [20] when they screened tomato germplasm for resistance to tomato yellow leaf curl virus disease in Ghana.

The overall mean incidences at the three locations differ significantly among them $\left(F_{2}, 288=\right.$ 75.48; $P<0.001$ ), with Bunso (forest ecology) having the highest $(30.79 \%)$ followed by UCC (coastal savannah) (10.74\%) and the lowest being Bawku (Sudan savannah) (5.62\%) as shown in Table 2. This finding is in agreement with that of Aliyu et al. [21] who reported that viral incidence is higher in the rain forest agro-ecology compared to the Guinea savannah agro-ecology in their study on the cowpea virus disease occurrence in Kwara State, Nigeria. Earlier studies by Panopoulos and Schroth [22] had shown that relative humidity is a key factor that determines the development of many diseases.
Khan et al. [23] also reported that humidity levels have a positive relationship with virus disease development. This suggests that the higher relative humidity in the forest ecology compared to the savannah ecology [21], at least, partly accounted for the higher disease incidence in the forest zone (Bunso) compared to the coastal savannah (UCC) and Sudan savannah (Bawku) zones. The significant locational effects on incidence of viral diseases have also been attributed to factors such as population dynamics of virus vectors, climatic conditions, cropping systems, cultivar types and virus inoculum levels [24]. Another cause of variation in the disease incidence at the various locations could be as a result of the presence of alternate host of the virus. Mathews and Dodds [25] reported that most plant viruses have weeds or other alternative natural hosts that provide a reservoir of viruses from which economically important crop plants may become infected. According to Hily et al. [26], plant viruses require alternate hosts to continue virus-host-vector association, which is crucial for the sustainability of the viral pathogens in the absence of the original crop host. Loebenstein and Thottappilly [27] observed the occurrence of Cowpea aphid-borne mosaic virus on Mucuna pruriens, which is a major vegetation cover of cowpeas on the field.

Genotype $\times$ location ( $G \times L$ ) interaction effect on mean disease incidence was not significantly different $\left(F_{62}, 288=0.57 ; P=0.014\right)$ (Table 6). This indicates that irrespective of the ecological zone, reaction of the cowpea genotypes to viral infection was stable. This supports the report of Ojuederie et al. [28] who indicated that the reaction of various cowpea genotypes to viral diseases is genotype dependent. This suggests that a cowpea genotype found to be resistant to virus disease at forest ecology will also be resistant when grown at the coastal savannah or Sudan savannah ecologies.

\subsection{Mean Severity of Viral Diseases}

ANOVA on final severity of virus disease showed significant differences among the cowpea genotypes planted at Bawku $\left(\mathrm{F}_{31,93}=1.88\right.$; $\mathrm{P}=$ $0.011)$ and Bunso $\left(F_{31}, 93=1.62 ; P=0.040\right)$ but did not show any significant difference at UCC $\left(F_{31}, 93=1.08 ; P=0.381\right)$ (Table 4). At Bawku, the disease severity scores ranged from 1.00 (symptomless) for genotypes UCC-11, UCC-241, UCC-366, UCC-466, UCC-473, UC-C-478, UCC514, Apagbaala, IT97K-499-35 and UCC-White to 1.167 (mild infection) for genotype UCC-32 (Table 3). Disease severity score at Bunso 
ranged from 1.00 (symptomless) for genotype UCC-484 to 2.11 (moderate infection) for genotype UCC-Early. Also, the mean final viral disease severity scores for the cowpea genotypes at UCC ranged from 1.0 (symptomless) for Apagbaala to 2.935 (moderate infection) for IT97K-499-35 (Table 3). These variations in disease severity scores could be due to interaction effects between different host genotypes and that of viral pathogens and the vector biotypes that were present. Differential response of genotypes has been reported by Gremillion et al., [29] to be common in disease resistance screening and can be attributed to differences in environmental conditions, pathogen variability and virulence. According to Salaudeen and Aguguom [30], it is a common phenomenon that a series of physiological changes are triggered as soon as a virus is introduced into a host plant such that susceptibility or resistance depends largely on the genetic background of the invaded plant. Another factor that could influence the response of the cowpea genotypes to viral disease is the ability of the plant to secrete certain chemicals into the environment which repelled the vectors. Tolerant accessions of tomatoes to Tomato yellow leaf curl virus have been reported by Osei et al. [20] to be associated with the presence of exudates from trichome glands on the leaf surface, in which whiteflies become entrapped. Other studies reported that density, length, and stiffness of trichomes affect whitefly preference to infest plant leaves [31]. This could explain the variations among the cowpea genotypes in the response to the viral disease infection.

The overall mean final severity score at the three locations were significantly different $\left(F_{2}, 288=\right.$ 17.04; $P<0.001$ ) (Table 6), with Bunso having the highest (1.35), followed by UCC (1.134) while Bawku had the lowest (1.035) (Table 3). The significant locational effect on mean disease severity scores could probably be due to the population of virus vectors, climatic conditions, type(s) of cultivars used for planting and alternate host of the virus in the ecological zones, as reported by Wisler et al. [24]. Moreover, these differences in reaction have been attributed to the virus strain, vector, genotype or altered feeding conditions of the vector at various ecological zones [32,33]. Orawu et al. [34] indicated that favourable climatic conditions can prolong vector migration, enhance vector population and consequently, increase their potential to transmit the virus in wheat stands. Bukvayová et al. [35] also attributed the epidemiology of vector- transmissible viruses to be related to weather conditions. Significant variation in disease severity scores among at the various locations could also be as a result of the presence of alternate host of the virus at the various locations. According to Sivalingam and Varma [36], ornamental plants and wild plants near crop fields seem to be infected with the viruses of cultivable plant species and play a key role in the development of virus disease epidemics. The alternate hosts provide a reservoir of viruses from which cowpea plants may become infected, as has been noted by Mathews and Dodds [25].

\section{Table 2. Mean final incidence of viral disease among 32 Cowpea Genotypes at Bawku, Bunso and UCC}

\begin{tabular}{|c|c|c|c|}
\hline \multirow[t]{2}{*}{ Genotype } & \multicolumn{3}{|c|}{ Mean incidence (\%) } \\
\hline & Bawku & Bunso & UCC \\
\hline Apagbaala & $0.00^{d}$ & $9.81 \mathrm{NS}$ & $0.00^{g}$ \\
\hline GH3684 & $6.02^{\mathrm{bcd}}$ & 25.45 & $8.39^{\text {cdefg }}$ \\
\hline IT97K-499-35 & $0.00^{d}$ & 35.67 & $17.20^{\text {bcdef }}$ \\
\hline SARC-LO2 & $4.19^{\text {cd }}$ & 21.87 & $6.02^{\text {efg }}$ \\
\hline UCC- Early & $10.21^{\mathrm{abcd}}$ & 59.94 & $23.02^{\mathrm{abc}}$ \\
\hline UCC-White & $0.00^{d}$ & 44.61 & $33.71^{a}$ \\
\hline UCC-11 & $0.000^{d}$ & 29.14 & $19.55^{\text {abcde }}$ \\
\hline UCC-24 & $4.17^{\mathrm{cd}}$ & 35.63 & $7.50^{\operatorname{defg}}$ \\
\hline UCC-32 & $21.02^{\mathrm{a}}$ & 44.09 & $16.78^{\text {bcdef }}$ \\
\hline UCC-56 & $13.52^{\mathrm{abc}}$ & 43.82 & $21.91^{\mathrm{abcd}}$ \\
\hline UCC-122 & $17.710^{\mathrm{ab}}$ & 36.33 & $12.05^{\text {bcdefg }}$ \\
\hline UCC-153 & $4.39^{\mathrm{cd}}$ & 26.86 & $8.39^{\text {cdefg }}$ \\
\hline UCC-221 & $8.372^{\mathrm{bcd}}$ & 25.45 & $4.19^{\text {fg }}$ \\
\hline UCC-226 & $4.19^{\text {cd }}$ & 43.58 & $4.19^{f g}$ \\
\hline UCC-241 & $0.00^{d}$ & 35.78 & $23.83^{\mathrm{ab}}$ \\
\hline UCC-328 & $6.024^{\mathrm{bcd}}$ & 9.81 & $11.69^{\text {bcdefg }}$ \\
\hline UCC-366 & $0.00^{\mathrm{d}}$ & 25.67 & $8.39^{\text {cdefg }}$ \\
\hline UCC-377 & $4.19^{\text {cd }}$ & 37.31 & $4.19^{f g}$ \\
\hline UCC-428 & $8.37^{\mathrm{bcd}}$ & 34.48 & $12.05^{\text {bcdefg }}$ \\
\hline UCC-445 & $8.37^{\text {bcd }}$ & 46.61 & $11.69^{\text {bcdefg }}$ \\
\hline UCC-460 & $8.37^{\mathrm{bcd}}$ & 28.53 & $11.71^{\text {bcdefg }}$ \\
\hline UCC-466 & $0.00^{d}$ & 22.50 & $4.19^{f g}$ \\
\hline UCC-471 & $4.186^{\mathrm{cd}}$ & 22.50 & $0.00^{g}$ \\
\hline UCC-473 & $0.00^{d}$ & 30.65 & $4.19^{f g}$ \\
\hline UCC-478 & $0.00^{d}$ & 18.29 & $0.00^{g}$ \\
\hline UCC-484 & $6.02^{\mathrm{bcd}}$ & 19.59 & $10.22^{\text {bcdefg }}$ \\
\hline UCC-489 & $11.69^{\mathrm{abcd}}$ & 34.78 & $15.89^{\text {bcdef }}$ \\
\hline UCC-490 & $14.39^{\mathrm{abc}}$ & 39.80 & $15.89^{\text {bcdef }}$ \\
\hline UCC-497 & $4.19^{\mathrm{cd}}$ & 22.89 & $8.39^{\text {cdefg }}$ \\
\hline UCC-513 & $4.19^{\mathrm{cd}}$ & 17.78 & $6.02^{\text {efg }}$ \\
\hline UCC-514 & $0.00^{d}$ & 22.50 & $4.19^{f g}$ \\
\hline UCC-523 & $6.02^{\mathrm{bcd}}$ & 34.34 & $8.39^{\text {cdefg }}$ \\
\hline Mean & 5.62 & 30.79 & 10.74 \\
\hline L.S.D 0.05 & 12.231 & 25.91 & 14.672 \\
\hline
\end{tabular}

${ }^{*} N S$ mean not significant. Means with the same alphabet in the same column are not significantly different from each other 
Genotype $x$ location $(G \times L)$ interaction effect on the mean severity scores were not significantly different $\left(F_{62}, 288=1.05 ; P=0.369\right)$, indicating that the overall host reaction were stable irrespective of the location. Thus, the mode of resistance demonstrated by the cowpea genotypes is stable at varying environmental conditions, indicating a steady state pathogenhost-environment interaction effect, as reported by Engering et al. [37]. This finding is contrary to that of Gibson et al. [38], who reported that genotypes or varieties behave differently when placed under different zones and that genotypes that perform better in the coastal zone may perform poorly in the forest zone and vice versa. Obeng et al., [39] also recommended that there is the need to screen or evaluate different accessions in different ecological zones in order to know their genetic diversity and how they respond to disease pressure, incidence, severity and physiological stress.

\section{Table 3. Overall cowpea reaction based on final severity at Bawku, Bunso and UCC}

\begin{tabular}{|c|c|c|c|c|c|c|}
\hline \multirow[t]{2}{*}{ Genotype } & Bawku & \multirow[t]{2}{*}{ HR } & \multirow{2}{*}{$\begin{array}{l}\text { Bunso } \\
\text { Mean severity }\end{array}$} & \multirow[t]{2}{*}{ HR } & UCC & \multirow[t]{2}{*}{ HR } \\
\hline & Mean severity & & & & Mean severity & \\
\hline Apagbaala & $1.000^{\mathrm{e}}$ & $\mathrm{R}$ & $1.050^{\mathrm{de}}$ & $\mathrm{R}$ & $1.000 \mathrm{NS}$ & $\mathrm{R}$ \\
\hline GH3684 & $1.042^{\text {cde }}$ & $\mathrm{R}$ & $1.300^{\mathrm{bcde}}$ & $\mathrm{R}$ & 1.040 & $\mathrm{R}$ \\
\hline IT97K-499-35 & $1.000^{\mathrm{e}}$ & $\mathrm{R}$ & $1.352^{\text {bcde }}$ & $\mathrm{R}$ & 2.935 & MR \\
\hline SARC-LO2 & $1.021^{\mathrm{de}}$ & $\mathrm{R}$ & $1.207^{\text {bcde }}$ & $\mathrm{R}$ & 1.062 & $\mathrm{R}$ \\
\hline UCC- Early & $1.062^{\text {bcde }}$ & $\mathrm{R}$ & $2.100^{\mathrm{a}}$ & MR & 1.201 & $\mathrm{R}$ \\
\hline UCC-White & $1.000^{\mathrm{e}}$ & $\mathrm{R}$ & $1.547^{\mathrm{bc}}$ & $\mathrm{R}$ & 1.312 & $\mathrm{R}$ \\
\hline UCC-11 & $1.000^{\mathrm{e}}$ & $\mathrm{R}$ & $1.257^{\text {bcde }}$ & $\mathrm{R}$ & 1.147 & $\mathrm{R}$ \\
\hline UCC-24 & $1.021^{\mathrm{de}}$ & $\mathrm{R}$ & $1.415^{\mathrm{bcd}}$ & $\mathrm{R}$ & 1.083 & $\mathrm{R}$ \\
\hline UCC-32 & $1.167^{\mathrm{a}}$ & $\mathrm{R}$ & $1.525^{\mathrm{bc}}$ & $\mathrm{R}$ & 1.080 & $\mathrm{R}$ \\
\hline UCC-56 & $1.104^{\mathrm{abc}}$ & $\mathrm{R}$ & $1.482^{\mathrm{bcd}}$ & $\mathrm{R}$ & 1.145 & $\mathrm{R}$ \\
\hline UCC-122 & $1.125^{\mathrm{ab}}$ & $\mathrm{R}$ & $1.325^{\text {bcde }}$ & $\mathrm{R}$ & 1.147 & $\mathrm{R}$ \\
\hline UCC-153 & $1.023^{\text {cde }}$ & $\mathrm{R}$ & $1.267^{\text {bcde }}$ & $\mathrm{R}$ & 1.040 & $\mathrm{R}$ \\
\hline UCC-221 & $1.044^{\text {bcde }}$ & $\mathrm{R}$ & $1.250^{\text {bcde }}$ & $\mathrm{R}$ & 1.020 & $\mathrm{R}$ \\
\hline UCC-226 & $1.021^{\mathrm{de}}$ & $\mathrm{R}$ & $1.565^{b c}$ & $\mathrm{R}$ & 1.020 & $\mathrm{R}$ \\
\hline UCC-241 & $1.000^{\mathrm{e}}$ & $\mathrm{R}$ & $1.450^{\mathrm{bcd}}$ & $\mathrm{R}$ & 1.185 & $\mathrm{R}$ \\
\hline UCC-328 & $1.042^{\text {cde }}$ & $\mathrm{R}$ & $1.100^{\text {cde }}$ & $\mathrm{R}$ & 1.083 & $\mathrm{R}$ \\
\hline UCC-366 & $1.000^{\mathrm{e}}$ & $\mathrm{R}$ & $1.600^{\mathrm{b}}$ & $\mathrm{R}$ & 1.040 & $\mathrm{R}$ \\
\hline UCC-377 & $1.021^{\mathrm{de}}$ & $\mathrm{R}$ & $1.407^{\text {bcd }}$ & $\mathrm{R}$ & 1.028 & $\mathrm{R}$ \\
\hline UCC-428 & $1.042^{\text {cde }}$ & $\mathrm{R}$ & $1.457^{\mathrm{bcd}}$ & $\mathrm{R}$ & 1.085 & $\mathrm{R}$ \\
\hline UCC-445 & $1.042^{\text {cde }}$ & $\mathrm{R}$ & $1.635^{\mathrm{ab}}$ & $\mathrm{R}$ & 1.103 & $\mathrm{R}$ \\
\hline UCC-460 & $1.062^{\text {bcde }}$ & $\mathrm{R}$ & $1.352^{\text {bcde }}$ & $\mathrm{R}$ & 1.083 & $\mathrm{R}$ \\
\hline UCC-466 & $1.000^{\mathrm{e}}$ & $\mathrm{R}$ & $1.250^{\mathrm{dcde}}$ & $\mathrm{R}$ & 1.020 & $\mathrm{R}$ \\
\hline UCC-471 & $1.021^{\mathrm{de}}$ & $\mathrm{R}$ & $1.250^{\text {bcde }}$ & $\mathrm{R}$ & 1.000 & $\mathrm{R}$ \\
\hline UCC-473 & $1.000^{\mathrm{e}}$ & $\mathrm{R}$ & $1.325^{\text {bcde }}$ & $\mathrm{R}$ & 1.020 & $\mathrm{R}$ \\
\hline UCC-478 & $1.000^{\mathrm{e}}$ & $\mathrm{R}$ & $1.192^{\text {bcde }}$ & $\mathrm{R}$ & 1.000 & $\mathrm{R}$ \\
\hline UCC-484 & $1.042^{\text {cde }}$ & $\mathrm{R}$ & $0.932^{\mathrm{e}}$ & $\mathrm{R}$ & 1.062 & $\mathrm{R}$ \\
\hline UCC-489 & $1.083^{\mathrm{bcd}}$ & $\mathrm{R}$ & $1.397^{\text {bcde }}$ & $\mathrm{R}$ & 1.103 & $\mathrm{R}$ \\
\hline UCC-490 & $1.083^{\mathrm{bcd}}$ & $\mathrm{R}$ & $1.500^{\mathrm{bcd}}$ & $\mathrm{R}$ & 1.103 & $\mathrm{R}$ \\
\hline UCC-497 & $1.021^{\mathrm{de}}$ & $\mathrm{R}$ & $1.180^{\text {bcde }}$ & $\mathrm{R}$ & 1.040 & $\mathrm{R}$ \\
\hline UCC-513 & $1.021^{\mathrm{de}}$ & $\mathrm{R}$ & $1.127^{\text {cde }}$ & $\mathrm{R}$ & 1.042 & $\mathrm{R}$ \\
\hline UCC-514 & $1.000^{\mathrm{e}}$ & $\mathrm{R}$ & $1.185^{\text {bcde }}$ & $\mathrm{R}$ & 1.020 & $\mathrm{R}$ \\
\hline UCC-523 & $1.042^{\text {cde }}$ & $\mathrm{R}$ & $1.350^{\text {bcde }}$ & $\mathrm{R}$ & 1.040 & $\mathrm{R}$ \\
\hline Mean & 1.0359 & & 1.354 & & 1.134 & \\
\hline L.S.D.0.05 & 0.08279 & 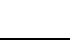 & 0.4719 & & 0.9091 & \\
\hline
\end{tabular}




\subsection{Mean Canopy Diameter and Plant Height at the Three (3) Agro- ecological Zones of Ghana}

Table 4 shows the plant height and mean canopy diameter attained by each of the accessions in the three agro-ecological zones. ANOVA on mean plant height showed significant differences among the cowpea genotypes at Bawku $\left(\mathrm{F}_{31}, 93=\right.$ 12.13; $P<0.001)$, Bunso $\left(F_{31}, 93=4.20 ; P<0.001\right)$ and UCC $\left(F_{31}, 93=7.61\right)$ (Table 4). At Bawku, the highest mean plant height $(63.85 \mathrm{~cm})$ was recorded for UCC-484 whilst Apagbaala had the lowest mean plant height $(9.65 \mathrm{~cm})$. At Bunso, genotype GH3684 had the highest mean plant height of $73.42 \mathrm{~cm}$ whilst the lowest $(35.23 \mathrm{~cm})$ was recorded for Apagbaala. At UCC, the highest mean plant height of $66.16 \mathrm{~cm}$ was recorded for UCC Early, whilst Apagbaala had the lowest plant height of $15.67 \mathrm{~cm}$ (Table 4).

ANOVA on mean canopy diameter showed significant difference amongst the genotypes at Bawku $\left(F_{31}, 93=10.96 ; P<0.001\right)$, Bunso (F31, 93 $=940.84 ; \mathrm{P}<0.001)$ and $\operatorname{UCC}\left(\mathrm{F}_{31}, 93=2.52\right.$; $P<0.001$ ) (Table 4). At Bawku, the highest mean canopy diameter of $69.8 \mathrm{~cm}$ was recorded for UCC-484 whilst genotypes UCC-497 had the lowest mean canopy diameter of $33 \mathrm{~cm}$. At Bunso, the highest mean canopy diameter of $289.2 \mathrm{~cm}$ was recorded for genotype UCC-513, whilst genotype UCC-24 had the lowest (33.5 $\mathrm{cm})$. At UCC, GH3684 had the highest mean canopy diameter of $73.83 \mathrm{~cm}$ whilst the lowest $(42.98 \mathrm{~cm})$ was recorded for genotype UCC-24.

These variations in plant height and canopy diameter could be due to genetic background of the various cowpea genotypes, as reported by Jindal et al. [40]. These variations in plant height and canopy diameter could also be as a result of the effect of the virus on the growth of the genotypes. This is in agreement with work done by Jindal et al. [40] which stated that infection of the genotypes by viruses may cause abnormality in plant growth hence hindering plant growth such as plant height, number of branches.

Locational effects on the overall mean plant height and canopy diameter were also highly significant $(P<0.001)$. Bunso had the highest mean plant height of $51.44 \mathrm{~cm}$, followed by UCC $(32.67 \mathrm{~cm})$ whereas Bawku had the lowest $(22.86 \mathrm{~cm})$. Similarly, Bunso had the highest mean canopy diameter of $169.64 \mathrm{~cm}$, followed by
UCC $(60.10 \mathrm{~cm})$ while Bawku had the lowest $(41.13 \mathrm{~cm})$. The observed variation in growth in terms of plant height and canopy diameter due to locational effect could be attributed to differences in climatic conditions (rainfall and temperature) and soil fertility levels. Bunso and Cape Coast have relatively better soil fertility levels and also experience higher rainfall compared to Bawku, which is in Sudan savannah area. This corroborates the work done by Addo-Quaye et al. [41] in their study on the performance of three cowpeas varieties in two agro-ecological zones of the Central region of Ghana.

The ANOVA showed significant genotype $x$ location (GXE) interaction effects $(P<0.05)$ on mean plant height $\left(F_{62,288}=1.83 ; \mathrm{P}<0.001\right)$ and mean canopy diameter $\left(F_{62,288}=170.01\right.$; $\mathrm{P}<0.001)$ recorded for the cowpea genotypes (Table 6). For instance, genotype UCC-484 had higher mean plant height $(63.85 \mathrm{~cm})$ at Bawku followed by Bunso which had a mean plant height of $58.52 \mathrm{~cm}$ while the lowest plant height $(35.78 \mathrm{~cm})$ was recorded at UCC. This suggests that plant growth is highly influenced by environmental factors, and that specific cowpea genotypes are adapted to specific environments. This corroborates the finding of Nwadike et al. [42] who reported a significant GxE interaction effect for certain growth parameters in their study on Genotype - Environment Interaction for plant development and some yield components in common bean (Phaseolus vulgaris L.) during the 2012 wet season.

\subsection{Average Yield Performance of Cowpea Accessions Evaluated at Three (3) Agro-ecological Zones of Ghana}

Mean 100 seed weight $(\mathrm{g})$ and the seed yield $(\mathrm{t}$ ha-1) produced by each of the genotypes tested are shown in Table 5. ANOVA on 100 seed weight showed significant difference amongst the cowpea genotypes at Bawku $\left(F_{30}, 93=11.32\right.$; $\mathrm{P}<0.001)$, Bunso $\left(\mathrm{F}_{31}, 93=11.32 ; \mathrm{P}<0.001\right)$ and UCC $\left(F_{31}, 96=4.30 ; P<0.001\right)$. The100 seed weight values recorded at Bawku, ranged from $11.47 \mathrm{~g}$ recorded for UCC-Early to $19.57 \mathrm{~g}$ recorded for SARC-LO2. At Bunso, the 100 seed weight values ranged from $13.53 \mathrm{~g}$ recorded for Apagbaala to $24.47 \mathrm{~g}$ recorded for genotype UCC-32; And at UCC, 100 seed weight values ranged between $13.75 \mathrm{~g}$ for $\mathrm{GH} 3684$ and $21 \mathrm{~g}$ recorded for UCC-24. 
Table 4. Mean canopy diameter and plant height of cowpea genotypes at the three agroecological zones

\begin{tabular}{|c|c|c|c|c|c|c|}
\hline \multirow[t]{2}{*}{ Accession } & \multicolumn{3}{|c|}{ Canopy diameter (cm) } & \multicolumn{3}{|c|}{ Plant height (cm) } \\
\hline & Bawku & Bunso & UCC & Bawku & Bunso & UCC \\
\hline Apagbaala & $32.15^{\mathrm{C}}$ & $35.2^{q}$ & $53.91^{\text {efghi }}$ & $9.65^{e}$ & $35.23^{n}$ & 15.67 \\
\hline $\mathrm{GH} 3684$ & $54.15^{\mathrm{ab}}$ & $73.4^{\mathrm{m}}$ & $73.83^{a}$ & $59.45^{\mathrm{a}}$ & $73.42^{\mathrm{a}}$ & $45.13^{\mathrm{bcd}}$ \\
\hline IT97K-499-35 & $41.45^{\mathrm{bc}}$ & $51.0^{\text {no }}$ & $61.62^{\text {bcdefgh }}$ & $22.80^{\text {cde }}$ & $51.00^{\text {cdefghijklm }}$ & $31.59^{\text {efghij }}$ \\
\hline SARC LO2 & $68.90^{\mathrm{a}}$ & $53.1^{\text {no }}$ & $63.47^{\text {abcdef }}$ & $47.35^{\mathrm{ab}}$ & $53.12^{\text {cdefghij }}$ & $45.02^{b c d}$ \\
\hline UCC-Early & $36.35^{\mathrm{bc}}$ & $59.6^{n}$ & $71.94^{\mathrm{ab}}$ & $31.05^{\text {bcde }}$ & $59.63^{\text {abcdef }}$ & $66.16^{a}$ \\
\hline UCC-White & $33.85^{c}$ & $50.6^{\circ}$ & $54.03^{\text {efghi }}$ & $17.80^{\text {cde }}$ & $50.58^{\text {defghijklm }}$ & $35.50^{\text {cdefgh }}$ \\
\hline UCC-11 & $45.55^{\mathrm{bc}}$ & $41.0^{p q}$ & $64.88^{\text {abcde }}$ & $35.85^{\mathrm{bc}}$ & $71.00^{\mathrm{ab}}$ & $46.58^{\mathrm{bc}}$ \\
\hline UCC-24 & $36.55^{\mathrm{bc}}$ & $33.5^{q}$ & $42.98^{i}$ & $20.90^{\text {cde }}$ & $43.08^{\text {hijklmn }}$ & $23.57^{\mathrm{jjkl}}$ \\
\hline UCC-32 & $35.10^{\mathrm{bc}}$ & $48.2^{\text {op }}$ & $57.04^{\text {defgh }}$ & $20.00^{\text {cde }}$ & $64.40^{\mathrm{abcd}}$ & $30.07^{\text {efghijk }}$ \\
\hline UCC-56 & $36.50^{\mathrm{bc}}$ & $52.6^{\text {no }}$ & $59.59^{\text {cdefgh }}$ & $20.15^{\text {cde }}$ & $49.12^{\text {efghijklmn }}$ & $26.64^{\text {fghijkl }}$ \\
\hline UCC-122 & $36.95^{\mathrm{bc}}$ & $84.2^{1}$ & $56.79^{\operatorname{defgh}}$ & $15.05^{\mathrm{cde}}$ & $46.42^{\text {fghijklmn }}$ & $27.51^{\text {efghijk }}$ \\
\hline UCC-153 & $41.10^{\mathrm{bc}}$ & $107.7^{k}$ & $66.18^{\mathrm{abcd}}$ & $22.50^{\text {cde }}$ & $62.42^{\text {abcde }}$ & $36.96^{\text {cdef }}$ \\
\hline UCC-221 & $35.05^{\mathrm{bc}}$ & $132.8^{\mathrm{j}}$ & $53.26^{\text {fghi }}$ & $12.95^{\mathrm{cde}}$ & $44.54^{\text {ghijklmn }}$ & $21.02^{\mathrm{jkl}}$ \\
\hline UCC-226 & $33.70^{c}$ & $132.0^{\mathrm{j}}$ & $51.51^{\mathrm{hi}}$ & $11.6^{\mathrm{de}}$ & $37.96^{\mathrm{klmn}}$ & $19.81^{\mathrm{kl}}$ \\
\hline UCC-241 & $41.80^{\mathrm{bc}}$ & $142.5^{\mathrm{i}}$ & $66.09^{\mathrm{abcd}}$ & $19.35^{\text {cde }}$ & $44.04^{\text {ghijklmn }}$ & $34.47^{\text {defghi }}$ \\
\hline UCC-328 & $35.70^{\mathrm{bc}}$ & $185.5^{\mathrm{h}}$ & $51.83^{\mathrm{ghi}}$ & $14.30^{\text {cde }}$ & $43.00^{\text {hijklmn }}$ & $18.71^{\mathrm{kl}}$ \\
\hline UCC-366 & $46.35^{\mathrm{bc}}$ & $219.2^{g}$ & $66.10^{\mathrm{abcd}}$ & $25.60^{\text {bcde }}$ & $72.50^{\mathrm{ab}}$ & $55.92^{\mathrm{ab}}$ \\
\hline UCC-377 & $38.65^{b c}$ & $210.9^{g}$ & $61.35^{\text {bcdefgh }}$ & $13.35^{\text {cde }}$ & $44.71^{\text {ghijklmn }}$ & $28.01^{\text {efghijk }}$ \\
\hline UCC-428 & $44.95^{\mathrm{bc}}$ & $240.1^{f}$ & $61.50^{\text {bcdefgh }}$ & $20.10^{\text {cde }}$ & $52.19^{\text {cdefghijk }}$ & $36.36^{\text {cdefg }}$ \\
\hline UCC-445 & $35.75^{b c}$ & $249.0^{\text {ef }}$ & $59.31^{\text {cdefgh }}$ & $16.45^{\text {cde }}$ & $53.04^{\text {cdefghij }}$ & $27.51^{\text {efghijk }}$ \\
\hline UCC-460 & $48.65^{\mathrm{bc}}$ & $254.0^{\text {de }}$ & $58.12^{\text {cdefgh }}$ & $31.15^{\text {bcde }}$ & $48.08^{\text {efghijklmn }}$ & $38.87^{\text {cde }}$ \\
\hline UCC-466 & $39.50^{\mathrm{bc}}$ & $253.2^{\mathrm{e}}$ & $58.63^{\text {cdefgh }}$ & $18.55^{\text {cde }}$ & $40.31^{\mathrm{ijk} k \mathrm{mn}}$ & $28.19^{\text {efghijk }}$ \\
\hline UCC-471 & $38.05^{b c}$ & $254.0^{\text {de }}$ & $56.64^{\text {defgh }}$ & $12.40^{\text {de }}$ & $36.44^{\mathrm{mn}}$ & $23.24^{\mathrm{j} k \mathrm{kl}}$ \\
\hline UCC-473 & $41.55^{\mathrm{bc}}$ & $255.0^{\text {de }}$ & $58.32^{\text {cdefgh }}$ & $33.35^{\mathrm{bcd}}$ & $36.98 \mathrm{I}^{\mathrm{mn}}$ & $23.22^{\mathrm{ijkl}}$ \\
\hline UCC-478 & $36.95^{\mathrm{bc}}$ & $262.9^{\mathrm{cd}}$ & $52.78^{\text {fghi }}$ & $17.90^{\text {cde }}$ & $47.83^{\text {efghijklmn }}$ & $23.99^{\text {hijkl }}$ \\
\hline UCC-484 & $69.80^{\mathrm{a}}$ & $271.3^{b c}$ & $62.63^{\text {abcdefgh }}$ & $63.85^{\mathrm{a}}$ & $58.52^{\text {bcdefg }}$ & $35.78^{\text {cdefg }}$ \\
\hline UCC-489 & $41.50^{b c}$ & $271.9^{b}$ & $63.17^{\text {abcdefg }}$ & $22.80^{\text {cde }}$ & $54.79^{\text {cdefghi }}$ & $50.98^{b}$ \\
\hline UCC-490 & $34.05^{\mathrm{bc}}$ & $275.1^{\mathrm{b}}$ & $65.09^{\text {abcde }}$ & $11.20^{\mathrm{de}}$ & $60.21^{\text {abcdef }}$ & $25.56^{\text {fghijkl }}$ \\
\hline UCC-497 & $33.00^{c}$ & $267.8^{\mathrm{bc}}$ & $59.86^{\text {cdefgh }}$ & $10.55^{\mathrm{de}}$ & $38.54^{\mathrm{jklmn}}$ & $27.83^{\text {efghijk }}$ \\
\hline UCC-513 & $39.10^{b c}$ & $289.2^{\mathrm{a}}$ & $69.52^{\mathrm{abc}}$ & $13.45^{\text {cde }}$ & $65.50^{\mathrm{abc}}$ & $38.49^{\text {cde }}$ \\
\hline UCC-514 & - & $285.0^{\mathrm{a}}$ & $55.81^{\text {defgh }}$ & - & $55.92^{\text {cdefgh }}$ & $25.00^{\text {ghijkl }}$ \\
\hline UCC-523 & $42.45^{\mathrm{bc}}$ & $287.2^{\mathrm{a}}$ & $65.29^{\text {abcde }}$ & $17.20^{\text {cde }}$ & $51.49^{\text {cdefghijkl }}$ & $32.00^{\text {efghij }}$ \\
\hline Mean & 41.13 & 169.64 & 60.10 & 22.86 & 51.44 & 32.67 \\
\hline L.S.D.0.05 & 9.887 & 8.935 & 11.484 & 11.245 & 14.638 & 11.581 \\
\hline
\end{tabular}

This finding agrees with that of Cobbinah et al [43] who found highly significant varietal differences in seed weight among 134 cowpea accessions in Ghana. Molosiwa et al. [44] also found significant difference in 100 seed weight among 432 cowpea accessions tested in Botswana. Okafor [45] had earlier found significant difference in 100 seed weight among nine cowpea varieties tested in Nigeria. Differences in 100 seed weight among the cowpea genotypes suggests that they have different seed sizes.

Seed yield $\left(\mathrm{t} \mathrm{ha}^{-1}\right)$ among the cowpea genotypes also varied significantly $(P<0.01)$ among them at Bawku $\left(F_{31}, 93=6.35 ; P<0.001\right)$ and Bunso $\left(F_{31}, 93\right.$ $=2.05 ; \mathrm{P}=0.004)$ but non-significant at UCC $\left(F_{31}, 93=1.54 ; P=0.059\right)$ (Table 5). At Bawku, seed yield ranged from $0 \mathrm{t} \mathrm{ha}^{-1}$ for genotype UCC-484 to $2.148 \mathrm{t} \mathrm{ha}^{-1}$ for genotype UCC-523. At Bunso, the seed yield ranged from $0.522 \mathrm{t} \mathrm{ha}^{-1}$ for UCC-11 to $2.451 \mathrm{t} \mathrm{ha}^{-1}$ for UCC-473. At UCC the seed yield ranged between $3.166 \mathrm{t} \mathrm{ha}^{-1}$ for UCC-484 to $9.891 \mathrm{t} \mathrm{ha}^{-1}$, recorded for UCC-366 (Table 5). Variation in seed yield have also been observed among 134 cowpea accessions tested in Ghana [43] and among 432 cowpea accessions tested in Botswana [44]. It has been reported that seed weight, which is a measure of seed size, has been found to be moderately to highly heritable with heritability estimate averaging 67.8 percent [46].

Locational effects on 100 seed weight and seed yield ( $t$ ha-1) were also significant $(P<0.05)$ (Table 6). The highest mean 100 seed weight 
was recorded at Bunso $(19.21 \mathrm{~g})$, followed by UCC (17.91 g) while Bawku had the lowest (15.35 g) (Table 5). However, UCC had the highest mean seed yield of $5.25 \mathrm{tha}^{-1}$, followed by Bawku (1.188 $\left.\mathrm{t} \mathrm{ha}^{-1}\right)$ whilst Bunso had the lowest (1.186 t ha ${ }^{-1}$ ) (Table 5). This finding is consistent with that of Cobbinah et al. [43] who reported of higher 100 seed weight and higher seed yield at Bunso, a forest ecology, than Pokuase, a coastal savannah ecology. According to them the better yield performance recorded at Bunso may be due to better climatic conditions in the semi-deciduos forest where Bunso is located compared to Pokuase, which is located in the coastal savannah. This corroborates the finding by Addo-Quaye et al. [41] where higher grain yield was recorded at Twifo Hemang, forest ecology, than in Cape Coast, coastal savannah ecology. It has been reported that locationspecific conditions of temperature, rainfall and soil factors determine the final seed yield [47]. Sangakkara [48] also observed that planting cowpea in the wet season produced the highest grain yields.

Table 5. Mean 100 Seed Weight and Seed Yields of Cowpea Genotypes at the Three Agroecological zones

\begin{tabular}{|c|c|c|c|c|c|c|}
\hline \multirow[t]{2}{*}{ Accession } & \multicolumn{3}{|c|}{100 seed weight $(\mathrm{g})$} & \multicolumn{3}{|c|}{ Seed yield $\left(t \mathrm{ha}^{-1}\right)$} \\
\hline & Bawku & Bunso & UCC & Bawku & Bunso & UCC \\
\hline Apagbaala & $12.00^{j}$ & $13.53^{m}$ & $16.25^{\mathrm{ijk}}$ & $0.974^{\text {ghij }}$ & $0.635^{g h}$ & $3.484^{\mathrm{ef}}$ \\
\hline GH3684 & $12.03^{j}$ & $15.28^{\mathrm{klm}}$ & $13.75^{\prime}$ & $1.413^{\operatorname{defg}}$ & $1.212^{\text {bcdefgh }}$ & $5.021^{\text {bcdef }}$ \\
\hline IT97K-499-35 & $14.45^{\mathrm{hi}}$ & $18.81^{\text {ghi }}$ & $17.50^{\text {defghi }}$ & $1.634^{\mathrm{abcd}}$ & $1.653^{\mathrm{abc}}$ & $6.824^{\mathrm{abcde}}$ \\
\hline SARC LO2 & $19.58^{a}$ & $19.58^{\text {defghi }}$ & $19.00^{\text {abcdef }}$ & $0.791^{\mathrm{ij}}$ & $1.346^{\text {bcdefgh }}$ & $4.897^{\text {bcdef }}$ \\
\hline UCC-Early & $11.48^{j}$ & $15.03^{\mathrm{Im}}$ & $14.25^{\mathrm{kl}}$ & $0.909^{\text {ghij }}$ & $1.333^{\text {bcdefgh }}$ & $6.102^{\text {bcdef }}$ \\
\hline UCC-White & $11.95^{\mathrm{j}}$ & $15.73^{\mathrm{kl}}$ & $14.50^{\mathrm{jkl}}$ & $0.549^{j}$ & $0.815^{\text {cdefgh }}$ & $3.058^{f}$ \\
\hline UCC-11 & $16.53^{\text {bcde }}$ & $18.72^{\text {ghij }}$ & $18.50^{\text {cdetgh }}$ & $2.074^{\mathrm{ab}}$ & $0.522^{h}$ & $7.370^{\mathrm{abc}}$ \\
\hline UCC-24 & $16.43^{\text {bcde }}$ & $21.93^{\mathrm{bc}}$ & $21.00^{\mathrm{a}}$ & $1.093^{\text {efghi }}$ & $1.276^{\text {bcdefgh }}$ & $3.518^{\mathrm{ef}}$ \\
\hline UCC-32 & $16.83^{b}$ & $24.47^{a}$ & $20.75^{\mathrm{ab}}$ & $1.070^{\text {efghij }}$ & $1.531^{\text {bcdef }}$ & $4.297^{\text {bcdef }}$ \\
\hline UCC-56 & $15.95^{\text {bcdef }}$ & $17.95^{\mathrm{ij}}$ & $18.25^{\text {cdefghi }}$ & $1.167^{\text {defghi }}$ & $0.717^{\text {efgh }}$ & $4.379^{\text {bcdef }}$ \\
\hline UCC-122 & $15.93^{\text {bcdefg }}$ & $19.67^{\text {defghi }}$ & $18.00^{\text {cdefghi }}$ & $1.258^{\text {defghi }}$ & $0.979^{\text {bcdefgh }}$ & $4.175^{\text {bcdef }}$ \\
\hline UCC-153 & $15.78^{\text {bcdefgh }}$ & $19.30^{\text {efghi }}$ & $19.00^{\mathrm{abcdef}}$ & $1.054^{\text {fghij }}$ & $0.707^{\text {efgh }}$ & $6.298^{\mathrm{abcdef}}$ \\
\hline UCC-221 & $15.95^{\text {bcdef }}$ & $19.66^{\text {defghi }}$ & $18.75^{\text {bcdefg }}$ & $1.189^{\text {defghi }}$ & $1.354^{\text {bcdefgh }}$ & $3.450^{\mathrm{ef}}$ \\
\hline UCC-226 & $16.60^{\text {bcde }}$ & $20.53^{\text {cdefg }}$ & $20.00^{a b c}$ & $1.301^{\text {defghi }}$ & $0.794^{\text {defgh }}$ & $3.604^{\text {def }}$ \\
\hline UCC-241 & $16.15^{\text {bcde }}$ & $18.97^{\text {fghi }}$ & $18.50^{\text {cdefgh }}$ & $1.138^{\text {defghi }}$ & $0.616^{h}$ & $6.269^{\text {bcdef }}$ \\
\hline UCC-328 & $14.00^{i}$ & $18.98^{\text {fghi }}$ & $17.50^{\text {defghi }}$ & $1.081^{\text {efghi }}$ & $1.574^{\mathrm{bcd}}$ & $4.973^{\text {bcdef }}$ \\
\hline UCC-366 & $16.48^{\text {bcde }}$ & $20.14^{\text {cdefg }}$ & $19.50^{\mathrm{abcd}}$ & $1.234^{\text {defghi }}$ & $0.692^{\text {fgh }}$ & $9.891^{\mathrm{a}}$ \\
\hline UCC-377 & $16.50^{\text {bcde }}$ & $19.53^{\text {defghi }}$ & $19.25^{\mathrm{abcde}}$ & $1.527^{\text {cdef }}$ & $1.29^{\text {bcdefgh }}$ & $4.022^{\text {bcdef }}$ \\
\hline UCC-428 & $15.22^{\text {efghi }}$ & $20.52^{\text {cdefg }}$ & $18.00^{\text {cdefghi }}$ & $1.941^{\mathrm{abc}}$ & $0.842^{\text {cdefgh }}$ & $7.172^{\mathrm{abcd}}$ \\
\hline UCC-445 & $15.93^{\text {bcdefg }}$ & $20.11^{\text {cdefg }}$ & $18.50^{\text {cdefgh }}$ & $1.578^{\mathrm{bcde}}$ & $1.467^{\text {bcdefg }}$ & $7.509^{\mathrm{ab}}$ \\
\hline UCC-460 & $15.70^{\text {bcdefgh }}$ & $18.77^{\text {ghi }}$ & $17.75^{\text {defghi }}$ & $1.549^{\text {cdef }}$ & $1.068^{\text {bcdefgh }}$ & $4.574^{\text {bcdef }}$ \\
\hline UCC-466 & $15.27^{\text {defghi }}$ & $20.02^{\text {defgh }}$ & $18.25^{\text {cdefghi }}$ & $1.524^{\text {cdef }}$ & $0.919^{\text {cdefgh }}$ & $6.072^{\text {bcdef }}$ \\
\hline UCC-471 & $15.43^{\text {bcdefgh }}$ & $18.78^{\text {ghi }}$ & $17.00^{\text {fghi }}$ & $1.077^{\text {efghi }}$ & $0.881^{\text {cdefgh }}$ & $4.512^{\text {bcdef }}$ \\
\hline UCC-473 & $15.35^{\text {cdefghi }}$ & $19.27^{\text {efghi }}$ & $17.25^{\text {efghi }}$ & $1.097^{\text {efghi }}$ & $2.451^{\mathrm{a}}$ & $7.370^{\mathrm{abc}}$ \\
\hline UCC-478 & $16.73^{b c}$ & $20.96^{\text {bcde }}$ & $19.50^{\mathrm{abcd}}$ & $1.346^{\operatorname{defgh}}$ & $0.979^{\text {bcdefgh }}$ & $4.170^{\text {bcdef }}$ \\
\hline UCC-484 & $14.53^{\text {fghi }}$ & $16.89^{\mathrm{jk}}$ & $16.75^{\mathrm{ghi}}$ & $0.000^{k}$ & $1.784^{\mathrm{ab}}$ & $3.166^{\dagger}$ \\
\hline UCC-489 & $14.62^{\text {fghi }}$ & $18.12^{\mathrm{ij}}$ & $16.50^{\mathrm{hij}}$ & $1.137^{\text {defghi }}$ & $1.188^{\text {bcdefgh }}$ & $4.811^{\text {bcdef }}$ \\
\hline UCC-490 & $16.68^{\mathrm{bcd}}$ & $21.28^{\mathrm{bcd}}$ & $17.75^{\text {defghi }}$ & $0.883^{h i j}$ & $1.804^{\mathrm{ab}}$ & $5.040^{\text {bcdef }}$ \\
\hline UCC-497 & $15.73^{\text {bcdefgh }}$ & $20.43^{\text {cdeefg }}$ & $18.75^{\text {bcdefg }}$ & $0.959^{\text {ghij }}$ & $1.590^{\mathrm{bcd}}$ & $5.595^{\text {bcdef }}$ \\
\hline UCC-513 & $14.47^{\mathrm{hi}}$ & $20.66^{\text {cdef }}$ & $16.75^{\mathrm{ghi}}$ & $1.310^{\text {defghi }}$ & $1.327^{\text {bcdefgh }}$ & $3.800^{\text {cdef }}$ \\
\hline UCC-514 & & $22.70^{\mathrm{ab}}$ & $18.25^{\text {cdefghi }}$ & $0.000^{k}$ & $1.551^{\mathrm{bcde}}$ & $7.034^{\mathrm{abcde}}$ \\
\hline UCC-523 & $15.50^{\text {bcdefgh }}$ & $18.25^{\mathrm{hij}}$ & $17.75^{\text {defghi }}$ & $2.148^{a}$ & $1.110^{\text {bcdefgh }}$ & $5.703^{\text {bcdef }}$ \\
\hline Mean & 15.346 & 19.21 & 17.91 & 1.188 & 1.186 & 5.25 \\
\hline L.S.D.0.05 & 1.4164 & 1.847 & 2.248 & 0.5229 & 0.8470 & 3.600 \\
\hline
\end{tabular}


Table 6. Mean sum of squares for viral disease incidence, severity scores, growth and yield traits of 32 cowpea genotypes

\begin{tabular}{|c|c|c|c|c|c|c|c|}
\hline $\begin{array}{l}\text { Source of } \\
\text { variation }\end{array}$ & DF & DI & DS & $\mathbf{P H}$ & CD & 100SW & Yield \\
\hline Genotype (G) & 31 & $514.8^{*}$ & $0.2183 \mathrm{NS}$ & $1104.1^{\prime \prime}$ & $167.75^{\circ \prime}$ & $33.029^{* 1}$ & 4.316 \\
\hline Location (L) & 2 & $22907.0^{* *}$ & $3.4683^{* *}$ & $28378.4^{* *}$ & $624880.19^{* *}$ & $633.039^{* *}$ & $924.644^{* *}$ \\
\hline$G \times L$ & 62 & 174.0NS & $0.2144 \mathrm{NS}$ & $200.6^{* *}$ & $170.01^{* *}$ & $10.54^{* *}$ & $3.364^{*}$ \\
\hline Error & 288 & 303.5 & 0.2036 & 109.6 & 76.19 & 1.801 & 2.387 \\
\hline
\end{tabular}

Genotype $x$ location interaction effects on 100 seed weight $(\mathrm{g})$ and seed yield $\left(\mathrm{t} \mathrm{ha}^{-1}\right)$ were also significant $(P<0.05)$ (Table 6). For instance, while genotype UCC-523 had high yield $\left(5.703 \mathrm{t} \mathrm{ha}^{-1}\right)$ at UCC followed by Bawku (2.148 $\left.\mathrm{t} \mathrm{ha}^{-1}\right)$, it had the lowest seed yield $\left(1.110 \mathrm{t} \mathrm{ha}^{-1}\right)$ at Bunso (Table 5). This implies that yield is highly influenced by environmental factors, and also suggests adaptability of specific genotypes to specific locations. Similar result was obtained by Shiringani [49] who observed inconsistencies in seed yield at different locations. Shiringani [49] further indicated that the interaction between genotypes and environment on the seed yield is an indication of their sensitivity to the environment, mainly temperature and rainfall.

\section{CONCLUSIONS}

The study on the genotype $x$ location $(G \times L)$ screening of cowpea genotypes against viral infections revealed that all the cowpea genotypes at the various locations showed symptoms of viral diseases but at varying degrees. However, the levels of incidence and severity were generally low and varied significantly $(P<0.05)$ among the locations, with forest zone having the highest incidence of $30.79 \%$, and severity score of 1.354 whilst Sudan savanna zone had the lowest incidence of $5.62 \%$ and severity score of 1.036. Genotypes Apagbaala, UCC-366, UCC473, UCC-484, UCC-489, UCC-490, UCC-497, UCC-514 and UCC-523 showed field resistance (mild symptoms) at all three AEZs. Genotype $x$ location (GXL) interaction effects on mean incidence and severity were however, not significant $(P>0.05)$. The study also showed significant differences among genotypes, locations and GXL interaction effects on plant height, canopy diameter, 100-seed weight and seed yields $(P<0.05)$. The highest plant height and canopy diameter was recorded at Bunso (forest AEZ), followed by Cape Coast (coastal savannah AEZ) whilst Bawku (Sudan savannah $A E Z)$ had the lowest. Overall mean seed yield at
UCC (5.25 t ha $\left.{ }^{-1}\right)$ was significantly higher than Bunso $\left(1.186 \mathrm{t} \mathrm{ha}^{-1}\right)$ and Bawku $\left(1,188 \mathrm{t} \mathrm{ha}^{-1}\right)$. Genotype UCC-473 gave significantly higher seed yield at UCC (7.370 $\mathrm{t} \mathrm{ha}^{-1}$ ) and Bunso (2.451 t ha $\left.{ }^{-1}\right)$ but low yield at Bawku (1.097 t ha $\left.{ }^{-1}\right)$ while genotype UCC-523 gave high yield at Bawku (2.148 tha $\mathrm{t}^{-1}$ and UCC (5.703 tha $\left.\mathrm{th}^{-1}\right)$ but low yield at Bunso $\left(1.110 \mathrm{t} \mathrm{ha}^{-1}\right)$. Also, genotypes UCC-366, UCC-484, UCC-489, UCC-490, UCC497 and UCC-514 each gave higher seed yield at UCC but low yields at the other locations. Therefore genotypes that was resistant to viral infection and also gave high seed yields should be further evaluated and released as a variety for the locations where they performed better.

\section{COMPETING INTERESTS}

Authors have declared that no competing interests exist.

\section{ACKNOWLEGDEMENT}

We are highly indebted to the International Treaty on Plant Genetic Resources for Food and Agriculture (ITPGRFA) and the Food and Agriculture Organization (FAO) for their sponsorship.

\section{REFERENCES}

1. Langyintuo AS, Lowenberg-DeBoer J, Arndt C. Potential impacts of the proposed West African monetary zone on cowpea trade. Agricultural Economics. 2005; 33(s3):411-21.

2. Singh B, Ehlers J, Sharma B, Freire Filho $F$. Recent progress in cowpea breeding. Fatokun CA, Tarawali SA, Singh BB, Kormawa PM. 2002;22-40.

3. Timko MP, Ehlers JD, Roberts PA. Cowpea. Pulses, sugar and tuber crops: Springer. 2007;49-67.

4. Fernandez-Rivera S, Bationo A, Makinde $\mathrm{K}$, Odion B. Cowpea as a key factor for a 
new approach to integrated crop-livestock systems research in the dry savannas of West Africa. Challenges and Opportunities for Enhancing Sustainable Cowpea Production. 2002;233.

5. Sanginga N, Dashiell K, Diels J, Vanlauwe $\mathrm{B}$, Lyasse O, Carsky R, et al. Sustainable resource management coupled to resilient germplasm to provide new intensive cereal-grain-legume-livestock systems in the dry savanna. Agriculture, Ecosystems \& Environment. 2003;100(2):305-14. Vanlauwe B, Lyasse O. Cowpea rotation as a resource management technology for cereal-based systems in the savannas of West Africa. Challenges and Opportunities for Enhancing Sustainable Cowpea Production. 2002;252.

6. Vanlauwe $\mathrm{B}$, Lyasse $\mathrm{O}$. Cowpea rotation as a resource management technology for cereal-based systems in the savannas of West Africa. Challenges and Opportunities for Enhancing Sustainable Cowpea Production. 2002;252.

7. MoFA. Agriculture in Ghana: Facts and Figures. ed: Accra, Ghana: Statistics, Research, and Information Directorate; 2011.

8. Hampton RO, Thottappilly G, Rossel HW. Viral diseases of cowpea and their control by resistance-conferring genes. Advances in Cowpea Research. 1997;159-75.

9. Yadav A. Identification of a seedborne mosaic virus on cowpea [Vigna sinensis (L.) Savi]. Plant Archives. 2010;10(2):7935.

10. Taiwo MA, Kareem KT, Nsa IY, Hughes JDA. Cowpea viruses: Effect of single and mixed infections on symptomatology and virus concentration. Virology Journal. 2007;4(1):95.

11. Aliyu TH, Balogun OS, Adeoti OM. Pathogenic Responses of Cowpea (Vigna unguiculata) Inoculated with Cucumber Mosaic virus to soil amendment with neem leaf powder. Agrosearch. 2011;11(1):99110.

12. Hughes JdA, Odu BO. Plant virology in Sub-Saharan Africa: Proceedings of a conference organized by IITA; 2001. International Institute of Tropical Agriculture, Ibadan, Nigeria: IITA; 2003.

13. Lamptey PNL, Hamilton RI. A new cowpea strain of southern bean mosaic virus from Ghana. Phytopathology. 1974;64:1100-4.

14. Zettler F, Evans I, editors. Blackeye cowpea mosaic virus in Florida: Host range and incidence in certified cowpea seed. Proceedings of the Florida State Horticultural Society; 1972.

15. Karim FA. Survey of cowpea viral disease symptoms and detection of associated viruses in selected cowpea growing areas in Ghana: Kwame Nkrumah University of Science and Technology. Kumasi, Ghana; 2016.

16. Kulldorff $M$, Heffernan $R$, Hartman J, Assunção R, Mostashari F. A space-time permutation scan statistic for disease outbreak detection. PLoS Med. 2005; 2(3):e59.

17. Gumedzoe MY, Thottappilly G, Asselin A. Occurrence of southern bean mosaic virus (SVMV) in Togo and its interaction with some cowpea cultivars. African Crop Science Journal. 1996;4(2):215-22.

18. Galanihe LD, Priyantha MGDL, Yapa DR, Bandara HMS, Ranasinghe JADAR. Insect pest and disease incidences of exotic hybrids chilli pepper varieties grown in the low country dry zone of Sri Lanka. Annals of Sri Lanka. 2004;6:99-106.

19. Grumet R, Kabelka E, McQueen S, Wai T, Humphrey R. Characterization of sources of resistance to the watermelon strain of Papaya ringspot virus in cucumber: allelism and co-segregation with other potyvirus resistances. TAG Theoretical and Applied Genetics. 2000;101(3):46372.

20. Osei MK, Akromah R, Lamptey JNL, Quain MD. Phenotypic and molecular screening of some tomato germplasm for resistance to tomato yellow leaf curl virus disease in Ghana. African Journal of Agricultural Research. 2012;7(33):4675-84.

21. Aliyu TH, Balogun OS, Uddin II RO. Cowpea virus disease occurrence: implication for food security and sustainable development in Kwara StateNigeria. Albanian Journal of Agricultural Sciences. 2013;12(4):633.

22. Panopoulos NJ, Schroth MN. Role of flagellar motility in the invasion of bean leaves. Phytopathology. 1974;64:1389-97.

23. Khan AM, Qureshi RA, Gilani SA, Ullah F. Antimicrobial activity of selected medicinal plants of Margalla Hills, Islamabad, Pakistan. Journal of Medicinal Plants Research. 2011;5(18):4665-70.

24. Wisler GC, Duffus JE, Liu H-Y, Li RH. Ecology and epidemiology of whiteflytransmitted closteroviruses. Plant Disease. 1998;82(3):270-80. 
25. Mathews DM, Dodds JA. First Report of Angelonia flower break virus in Nemesia spp. and other ornamental plants in California. Plant Disease. 2008;92(4):651.

26. Hily JM, García A, Moreno A, Plaza M, Wilkinson MD, Fereres A, et al. The relationship between host lifespan and pathogen reservoir potential: An analysis in the system Arabidopsis thaliana-Cucumber mosaic virus. PLoS Pathog. 2014;10(11): e1004492.

27. Loebenstein G, Thottappilly G. Virus and virus-like diseases of major crops in developing countries: Springer Science \& Business Media; 2013.

28. Ojuederie OB, Odu BO, llori CO. Serological detection of seed borne viruses in cowpea regenerated germplasm using protein a sandwich enzyme linked immunorsorbent assay. African Crop Science Journal. 2009;17(3).

29. Gremillion SK, Culbreath AK, Gorbet DW, Mullinix Jr BG, Pittman RN, Stevenson KL, Todd JW, Escobar RE, Condori MM. Field evaluations of leaf spot resistance and yield in Peanut genotypes in the united states and Bolivia. Plant Disease. 2011; 95(3):263-8.

30. Salaudeen MT, Aguguom A. Identification of some cowpea accessions tolerant to cowpea mild mottle virus. Int $\mathrm{J}$ Sci Nature. 2014;5:261-7.

31. Taggar GK, Gill RS. Preference of whitefly, Bemisia tabaci, towards black gram genotypes: Role of morphological leaf characteristics. Phytoparasitica. 2012; 40(5):461.

32. Navas-Castillo J, Sánchez-Campos S, Díaz JA, Sáez-Alonso E, Moriones E. Tomato yellow leaf curl virus-ls causes a novel disease of common bean and severe epidemics in tomato in Spain. Plant Disease. 1999;83(1):29-32.

33. Delatte $T$, Umhang $M$, Trevisan $M$, Eicke S, Thorneycroft D, Smith SM, et al. Evidence for distinct mechanisms of starch granule breakdown in plants. Journal of Biological Chemistry. 2006;281(17): 12050-9

34. Orawu M, Adipala E, Warren H, editors. Influence of cowpea/sorghum intercropping on occurrences of disease and insect pests in Eastern Uganda. In. African Crop Science Conference Proceedings; 2001.

35. Bukvayová N, Henselová M, Vajcíková V, Kormanová T. Occurrence of dwarf virus of winter wheat and barley in several regions of Slovakia during the growing seasons 2001-2004. Plant Soil and Environment. 2006;52(9):392.

36. Sivalingam PN, Varma A. Non-tomato natural hosts of tomato infecting begomoviruses in north-western India. Indian Journal of Virology. 2007;18(1):207.

37. Engering $\mathrm{A}$, Hogerwerf L, Slingenbergh $\mathrm{J}$. Pathogen-host-environment interplay and disease emergence. Emerging Microbes \& Infections. 2013;2(2):e5.

38. Gibson RW, Mpembe I, Alicai T, Carey EE, Mwanga ROM, Seal SE, et al. Symptoms, aetiology and serological analysis of sweet potato virus disease in Uganda. Plant Pathology. 1998;47(1):95-102.

39. Obeng-Antwi K, Craufurd $P Q$, Menkir A, Ellis RH, Sallah PYK. Phenotypic diversity in maize landraces in Ghana. Int J Sci Adv Technol. 2012;5:39-70.

40. Jindal V, Dhaliwal GS, Dhawan AK, Dilawari VK. Mechanisms of resistance in cotton to whitefly (Bemisia tabaci): Tolerance. Phytoparasitica. 2009;37(3): 249-54.

41. Addo-Quaye AA, Darkwa AA, Ampiah MKP. Performance of three cowpea (Vigna unguiculata (L) Walp) varieties in two agroecological zones of the central region of Ghana I: Dry matter production and growth analysis. ARPN Journal of Agricultural and Biological Science. 2011; 6(2):1-9.

42. Nwadike C, Vange T, Ochigbo AE. Genotype - Environment Interaction for Plant Development and Some Yield Components in Common Bean (Phaseolus vulgaris L.) during the 2012 Wet Season. Greener Journal of Plant Breeding and Crop Science. 2014;2(1):001-8.

43. Cobbinah FA, Addo-Quaye AA, Asante IK. Characterization, evaluation and selection of Cowpea (Vigna unguiculata (L.) Walp) Accessions with desirable traits from eight Regions of Ghana. ARPN J Agric Biol Sci. 2011;6(7):21-32.

44. Molosiwa OO, Gwafila C, Makore J, Chite SM. Phenotypic variation in cowpea (Vigna unguiculata [L.] Walp.) germplasm collection from Botswana. International Journal of Biodiversity and Conservation. 2016;8(7):153-63.

45. Okafor LI. Adapting improved Cowpea cultivars to the Nigeria and Arid zone. Tropical Grain Legume Bulletin. 1986; 33:20. 
46. Fery RL. The genetics of cowpea: A review of the world literature. John Wiley \& Sons, Chichester, UK; 1985.

47. Padi FK, Marfo KO. Selection criteria for early maturing cowpea (Vigna unguiculata L. Walp.) genotypes in northern Ghana. Ghana J Agric Sci. 2005;1:79-86.

48. Sangakkara UR. Growth and yields of cowpea (Vigna unguiculata (L.) Walp) as influenced by seed characters, soil moisture and season of planting. Journal of Agronomy and Crop Science. 1998; 180(3):137-42.

49. Shiringani RP. Effects of planting date and location on phenology, yield and yield components among selected cowpea varieties: Agricultural Research Council; 2007.

(c) 2017 Vera et al.; This is an Open Access article distributed under the terms of the Creative Commons Attribution License (http://creativecommons.org/licenses/by/4.0), which permits unrestricted use, distribution, and reproduction in any medium, provided the original work is properly cited.

Peer-review history:

The peer review history for this paper can be accessed here: http://sciencedomain.org/review-history/19993 